\title{
Seabird ticks (Ixodes uriae) distribution along the Antarctic Peninsula
}

\author{
Andrés Barbosa $\cdot$ Jesús Benzal $\cdot$ Virginia Vidal $\cdot$ Verónica D’Amico $\cdot$ Nestor Coria $\cdot$ \\ Julia Diaz • Miguel Motas • María José Palacios • José Javier Cuervo • \\ Juana Ortiz $\cdot$ Lidia Chitimia
}

Received: 6 July 2010 / Revised: 15 March 2011 / Accepted: 18 March 2011 / Published online: 2 April 2011

(C) Springer-Verlag 2011

\begin{abstract}
The distribution of the tick Ixodes uriae is studied in the South Shetlands and different locations along the Antarctic Peninsula. Ticks were found beneath stones close to penguin rookeries of chinstrap, gentoo and adelie penguin, although no individuals were found parasitized. Our results showed that ticks are not distributed evenly along the Antarctic Peninsula being more common and abundant in the northern part with relative abundances of ticks ranging from 1 to 57 individuals per stone and from 2 to $26 \%$ of the stone inspected. Ticks are probably absent in the south.
\end{abstract}

Keywords Antarctic Peninsula $\cdot$ Distribution .

Ixodes uriae $\cdot$ Penguins $\cdot$ Ticks $\cdot$ South Shetlands

\footnotetext{
A. Barbosa $(\square)$

Department of Ecología Evolutiva, Museo Nacional de Ciencias Naturales, CSIC, C/José Gutiérrez Abascal, 2, 28006 Madrid, Spain

e-mail: barbosa@mncn.csic.es

Present Address:

J. J. Cuervo

Department of Ecología Evolutiva, Museo Nacional de Ciencias

Naturales, CSIC, C/José Gutiérrez Abascal, 2,

28006 Madrid, Spain

J. Benzal · M. J. Palacios · J. J. Cuervo

Department of Ecología Funcional y Evolutiva,

Estación Experimental de Zonas Áridas, CSIC,

Carretera de Sacramento s/n, 04120 La Cañada de San Urbano,

Almeria, Spain

V. Vidal $\cdot$ J. Ortiz $\cdot$ L. Chitimia

Department of Parasitología, Facultad de Veterinaria,

Universidad de Murcia, Murcia, Spain
}

\section{Introduction}

The tick Ixodes uriae White 1852 (Acari: Ixodidae) is widely distributed throughout circumpolar regions (Murray 1967; Health 1977). They are usually associated with seabird colonies, and more than 50 species have been recorded as host of this ectoparasite (Wilson 1970; Eveleigh and Threlfall 1974; Bergström et al. 1999). Tick effects on the host include delay in chick growth (Morbey 1996), chick mortality (Chastel et al. 1987; Bergström et al. 1999) and even adult mortality (Gauthier-Clerc et al. 1998). Changes in population dynamics have been also reported (Boulinier and Danchin 1996). However, other works show that tick infestations had no effect on different traits such as body mass, haematocrit, behaviour of incubating penguins, fidelity of breeding site or survival after 32 months

\footnotetext{
V. D'Amico

Centro Nacional Patagónico, CONICET,

Boulevard Brown 2825 U9120 ACF, Puerto Madryn,

Chubut, Argentina

N. Coria

Department Aves Marinas, Instituto Antártico Argentino,

Cerrito 1248 (C1010AAZ), Buenos Aires, Argentina

J. Diaz

Centro de Estudios Parasitológicos y de Vectores, CONICET, Universidad Nacional de La Plata, Calle 2 584, La Plata,

Buenos Aires, Argentina

M. Motas

Department of Toxicología. Facultad de Veterinaria,

Universidad de Murcia, Campus Espinardo, 30100 Murcia, Spain

L. Chitimia

Institute for Diagnosis and Animal Health, Street Dr. Staicovici, 63, Sector 5, 050557 Bucharest, Romania
} 
(Gauthier-Clerc et al. 2003). Ixodes uriae transmits different pathogenic agents like the bacteria Borrelia burdogferi responsible of the Lyme disease (Olsen et al. 1993) and some viruses (flavivirus, orbivirus, phlebovirus or nairovirus) as well (Nuttall 1984; Major et al. 2009). Currently, the known distribution of Ixodes uriae in Antarctica is restricted to Sub-Antarctic islands (Barbosa and Palacios 2009 and references therein) and the Palmer Archipelago (Benoit et al. 2007); however, there is no information about its distribution along the Antarctic Peninsula including the South Shetlands.

Information about the presence and distribution of parasite and pathogens in Antarctica is scarce and fragmented (Barbosa and Palacios 2009), and there is a need to know what is normal and aberrant in relation to factors potentially affecting the health of Antarctic wildlife (Kerry et al. 1999). To know the distribution of ticks is of great importance because they cause negative effects on seabird populations (Chastel et al. 1987; Bergström et al. 1999) but also for the possibility of zoonotic transmission. The aim of this note is to describe the distribution of this parasite in several locations along the western coast of Antarctic Peninsula.

\section{Materials and methods}

We visited several penguin rookeries located in the South Shetlands and along the Antarctic Peninsula in January of 2007 (Stranger Point, King George Island), 2009 (Devil's Point, Livingston Island; Hannah Point, Livingston Island; Deception Island) and 2010 [Stranger Point, King George Island; Hannah Point, Livingston Island; Deception Island; George Point, Ronge island; Yalour Island; Avian Island (Fig. 1)]. The penguin species and the population size present in each location is as follows: Stranger Point, King George Island (gentoo penguin-Pygoscelis рариа [3,764 pairs, Carlini et al. 2009] and adélie penguin-Pygoscelis adeliae [3,412 pairs, Carlini et al. 2009]); Hannah Point, Livingston Island (chinstrap penguin-Pygoscelis antarctica $[754$ pairs, Lynch et al. 2008] and gentoo penguin [1,885 pairs, Lynch et al. 2008]); Devil's Point, Livingston Island (chinstrap [50 pairs, own data] and gentoo penguin [3,000 pairs, own data]); Vapour Col, Deception Island (chinstrap penguin [12,000 pairs, own data]); George Point, Ronge Island (chinstrap [354 pairs, Lynch et al. 2008] and gentoo penguin [2,464 pairs, Lynch et al. 2008]); Yalour Island (adélie penguin [5,558 pairs, Lynch et al. 2008]) and Avian Island (adélie penguin [35,600 pairs, Management plan of ASPA number 117). Ticks were searched for beneath stones located within the penguin colonies. Stones were chosen by its proximity to the penguin colonies (range of

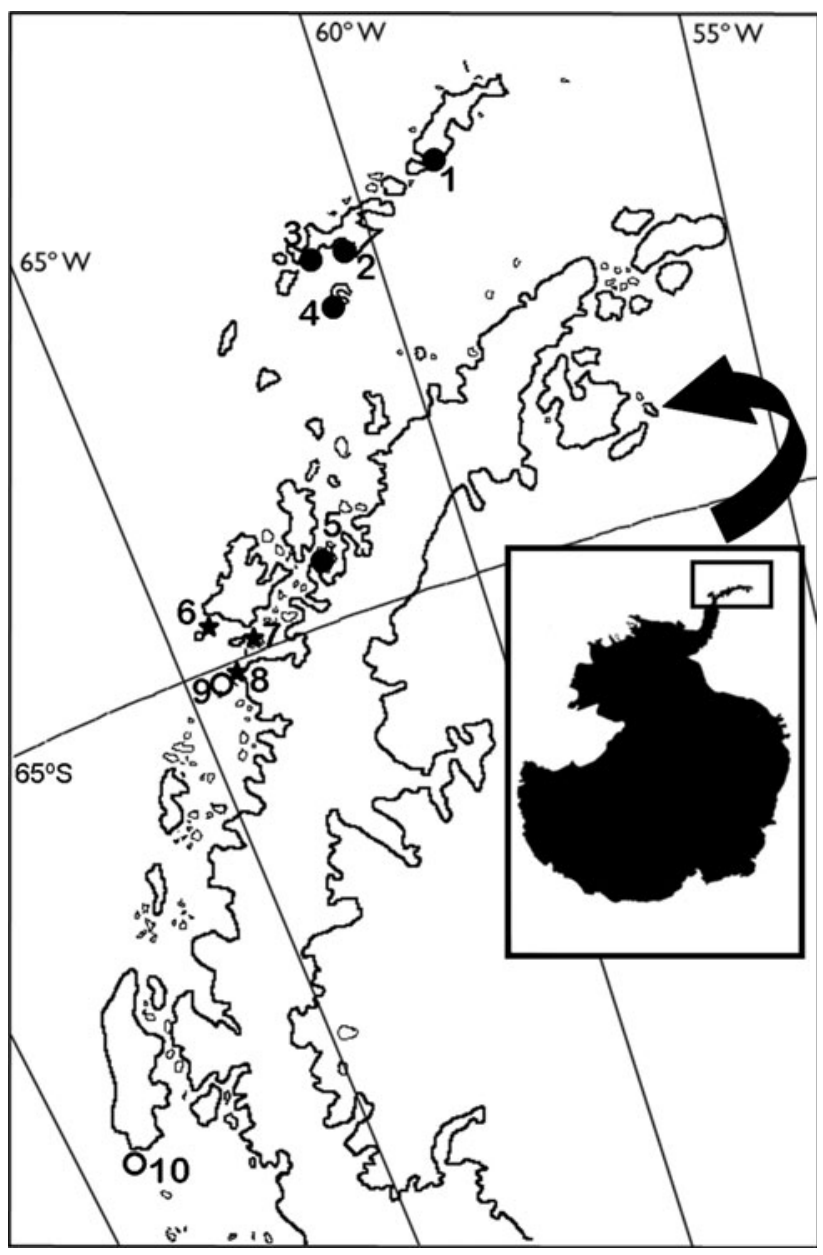

Fig. 1 Localities where ticks were sampled. Black circles: ticks present from this study. Stars: ticks present taken from literature. White circles: ticks absent from this study. 1. King George Island (Stranger Point, $62^{\circ} 15^{\prime} \mathrm{S} 58^{\circ} 37^{\prime} \mathrm{W}$ ), 2. Livingston Island (Hannah Point, $62^{\circ} 39^{\prime} \mathrm{S} 60^{\circ} 36^{\prime} \mathrm{W}$ ), 3. Livingston Island (Devils Point, 62 $40^{\prime} \mathrm{S}$

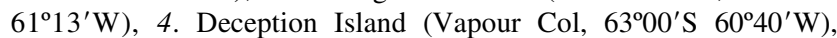
5. Ronge Island (George Point, $64^{\circ} 40^{\prime} \mathrm{S} 62^{\circ} 40^{\prime} \mathrm{W}$ ), 6. Humble island $\left(64^{\circ} 46^{\prime} \mathrm{S} 64^{\circ} 06^{\prime} \mathrm{W}\right), 7$. Doumer Island $\left(64^{\circ} 51^{\prime} \mathrm{S} 63^{\circ} 55^{\prime} \mathrm{W}\right), 8$. Petermann Island $\left(65^{\circ} 11^{\prime} \mathrm{S} 64^{\circ} 10^{\prime} \mathrm{W}\right), 9$. Yalour Island $\left(65^{\circ} 15^{\prime} \mathrm{S} 64^{\circ} 11^{\prime} \mathrm{W}\right)$, 10. Avian Island $\left(67^{\circ} 46^{\prime} \mathrm{S} 68^{\circ} 43^{\prime} \mathrm{W}\right)$

distance from the colony 0 to $3 \mathrm{~m}$ ) and by its size (not too big to be lifted). In 2007 and 2009, ticks were looked for opportunistically turning up stones until the ticks were found. In 2010, a more detailed survey was undertaken lifting between 50 and 100 stones in each location surveyed. During the survey, penguins were during the guard phase in all the locations. Relative abundance was calculated as the number of stone with ticks divided by the total number of stones prospected. The approximated number of ticks under each stone was also recorded.

Ticks were collected and preserved in $70 \%$ ethanol. Identification was carried out according to keys for this species (Hoogstraal 1954). 


\section{Results and discussion}

Ticks found were identified as Ixodes uriae. Eggs, larvae, nymphs, gravid females and males were found in Stranger Point (King George Island), Devil's Point (Livingston Island), Hannah Point (Livingston Island), Vapour Col (Deception Island) and George Point (Ronge Island). No ticks were found in Yalour Island and Avian Island. Mean number of ticks ( $\mathrm{x} \pm$ standard error) found in each location and relative abundance of stones with ticks were as follows: Stranger Point: $48.00 \pm 8.18,9 \%-9 / 100$; Devil's Point: $57.00 \pm 10.83$, 8\% - 4/50; Hannah Point: $38.57 \pm 8.18$, $10 \%$-5/50; Vapour Col: $49.16 \pm 8.84,26 \%-13 / 50$; George Point: $1.00 \pm 15.32,2 \%-2 / 100$; Yalour Island: $0.00 \pm 0.00,0 \%-0 / 100 ;$ Avian Island: $0.00 \pm 0.000 \%-$ $0 / 150$

From 2003 till 2010, these rookeries have been visited and penguins captured for different studies. The number of penguins captured ranged from 25 individuals in Devil's Point to more than a thousand in Vapour Col colony. No birds infected with ticks were found in these locations. In Antarctica, ticks seem to have only one blood meal per year (Lee and Baust 1987), and therefore, it could be difficult to find ticks on the hosts. However, Frenot et al. (2001) found infested penguins early in the breeding period and prevalence and infestation intensity increased rapidly during this period. Nevertheless, these authors carried out their study in Sub-Antarctic islands where the environmental conditions are warmer than in the Antarctic Peninsula. Therefore, it is likely that feeding activity of ticks could be reduced in Antarctic Peninsula making more difficult to find the ticks on the penguins.

In spite of the reported presence of ticks at least since the early 1980s in the Palmer Archipelago (64 $46^{\prime}$ S $\left.64^{\circ} 03^{\prime} \mathrm{W}\right)$ (Lee and Baust 1982; see also Casanueva and Moyano 2000), it has not been published any report on the distribution of this parasite in the western coast of the Antarctic Peninsula. Only recently, Lynch et al. (2010) reported the presence of a tick infestation on Adèlie penguins in Peterman Island during 2006/2007 and 2007/2008 breeding seasons. Therefore, no data exist to track the evolution of the populations of this parasite in Antarctica. This study is therefore the first one to provide results of a survey on the presence of ticks in this Antarctic region. Our results showed that ticks are not distributed evenly along the Antarctic Peninsula being more common and abundant in the northern part and probably absent in the south. This pattern fits with a likely northern origin of the colonization of ticks in Antarctica by means of eggs transport on migratory birds (Health 1977; Smith et al. 1996). This way is also hypothesized for the spreading of Borrelia sp. in the Southern Ocean (Olsen et al. 1995). Conversely, the presence of ticks in Antarctica could be constituted a relic of a Tertiary fauna separated by continental drift (Health 1977). However, detailed molecular studies are needed to account for the colonization and distribution of ticks in Antarctica.

Ticks are vectors of several bacteria and viruses (Olsen et al. 1993; Nuttall 1984). As far as we know excepting three studies carried out in Sub-Antarctic islands (Olsen et al. 1995; Gauthier-Clerc et al. 1999; Major et al. 2009), no other studies give data on the prevalence of these pathogens transmitted by ticks (i.e. Borrelia burdogferi) in continental Antarctica. These pathogens are expected to be present in Antarctica although in some cases in spite of the presence of ticks, B. burdogferi has not been detected (Olsen et al. 1995). Studies on this topic are also needed.

Finally, in Antarctic Peninsula temperatures have risen in the last 50 years (Steig et al. 2009). Ixodes uriae as an ectoparasite might be favoured by this fact as occurs with other tick species (Ogden et al. 2006). In fact, an increase in the number of feeding ticks has been related to higher temperatures in warmer years in Antarctic Peninsula (Benoit et al. 2009). Therefore, ticks could be an excellent indicator organism to track climate change in Antarctica.

Acknowledgments This study was funded by the Spanish Ministry of Science and Innovation projects CGL2004-01348, POL200605175, POL2006-06635, CGL2007-60369 and by the European Regional Development Fund. MJP was supported by a PhD grant from the Spanish Ministry of Science and Innovation (BES2005-8465). VV was supported by a PhD grant from the Spanish Council for Scientific Research (JAEPre08-01053). We thank the Spanish Antarctic base "Gabriel de Castilla", the Argentinean Antarctic base "Teniente Jubany", the Spanish polar ship "Las Palmas" and the Maritime Logistic Unit (CSIC) for logistic support and transport. Permission to work in the study area was given by the Spanish Polar Committee. This is a contribution to the International Polar Year project 172 BIRDHEALTH and to PINGUCLIM project. We thank an anonymous referee for helpful suggestions on an early version of this manuscript.

\section{References}

Barbosa A, Palacios MJ (2009) Health of Antarctic birds: a review of their parasites, pathogens and diseases. Polar Biol 32:10951115

Benoit JB, Yoder JA, Lopez-Martinez G, Elnitsky MA, Lee RE, Denlinger DL (2007) Habitat requirements of the seabird tick, Ixodes uriae (Acari: Ixodidae) from the Antarctic Peninsula in relation to water balance characteristics of eggs, nonfed and engorged stages. J Comp Physiol B 177:205-215

Benoit JB, Lopez-Martinez G, Elnitsky MA, Lee RE, Denlinger DL (2009) Increase in feeding by the tick Ixodes uriae on Adélie penguins during a prolonged summer. Antarct Sci 21:151-152

Bergström S, Haemig PD, Olsen B (1999) Distribution and abundance of the tick Ixodes uriae in a diverse subantarctic seabird community. J Parasitol 85:25-27

Boulinier T, Danchin E (1996) Population trends in Kittiwake Rissa tridactyla in relation to tick infestation. Ibis 138:326-334

Carlini A, Coria NR, Santos MM, Negrete J, Juares MA, Daneri GA (2009) Responses of Pygoscelis adeliae and P. papua to environmental changes at Isla 25 de Mayo (King George Island). Polar Biol 32:1427-1433 
Casanueva ME, Moyano HI (2000) Ixodes uriae White 1852 (Acari: Ixodidae) asociado con el pingüino papúa (Pygoscelis papua Forster), en la Península antártica. Gayana 64:2-3

Chastel C, Monnat JY, Le Lay G, Balouet G (1987) Infestation et hyperinfestation de la mouette tridactyle, Rissa tridactyla L. par des tiques (Ixodes (Ceratixodes) uriae, Ornithodoros (Alectorobius) maritimus). Consequences pathologiques. Ann Parasitol Hum Comp 62:492-504

Eveleigh ES, Threlfall W (1974) The biology of Ixodes (Ceratixodes) uriae White 1852 in Newfoundland. Acarologia 16:621-635

Frenot Y, de Oliveira E, Gauthier-Clerc M, Deunff J, Bellido A, Vernon P (2001) Life cycle of the tick Ixodes uriae in penguin colonies: relationship with host breeding activity. Int J Parasitol 31:10401047

Gauthier-Clerc M, Clerquin Y, Handrich Y (1998) Hyperinfestation by ticks Ixodes uriae: a possible cause of death in adult King penguins, a long lived seabird. Col Waterbirds 21:229-233

Gauthier-Clerc M, Jaulhac B, Frenot Y, Bachelard C, Monteil H, Le Mayo Y, Handrick Y (1999) Prevalence of Borrelia burgdorferi (the Lyme disease agent) antibodies in king penguin Aptenodytes patagonicus in Crocet Archipelago. Polar Biol 22:141-143

Gauthier-Clerc M, Manguin S, Le Bohec C, Gendner JP, Le Maho Y (2003) Comparison of behaviour, body mass, haematocrit level, site fidelity and survival between infested and non-infested king penguin Aptenodytes patagonicus by ticks Ixodes uriae. Polar Biol 26:379-382

Health ACG (1977) Zoogeography of the New Zealand tick fauna. Tuatara 23:26-40

Hoogstraal H (1954) Ixodes (Cratixodes) uriae White, 1952, parasitizing penguins and sea birds in the Falkland Islands (Ixodoidea, Ixodidae). J Parasitol 40:232

Kerry K, Riddle M, Clarke K (1999) Diseases of Antarctic wildlife. A report for SCAR and COMNAP, SCAR

Lee RE, Baust JG (1982) Respiratory metabolism of the Antarctic tick, Ixodes uriae. Comp Biochem Physiol 72A:167-171

Lee RE, Baust JG (1987) Cold-hardiness in Antarctic tick, Ixodes uriae. Physiol Zool 60:499-506
Lynch HJ, Naveen R, Fagan WF (2008) Censuses of penguins, blueeyed shags Phalacrocorax atriceps, and southern giant petrels Macronectes giganteus populations on the Antarctic Peninsula, 2001-2007. Marine Ornithol 36:83-97

Lynch HJ, Fagan WF, Naveen R (2010) Populations trends and reproductive success at a frequently visited penguin colony on the Western Antarctic Peninsula. Polar Biol 33:493-503

Major L, Linn ML, Slade RW, Schroder WA, Hyatt AD, Gardner J, Cowley J, Suhrbier A (2009) Ticks associated with Macquarie island penguins carry arboviruses from four genera. Plos One 4:1-12

Morbey YE (1996) The abundance and effects of ticks (Ixodes uriae) on nestlings Cassin's Auklets (Ptychorramphus aleuticus) at Triangle Islands, British Columbia. Can J Zool 74:1585-1589

Murray MD (1967) Ectoparasites of Antarctic seals and birds. JARE Sci Rep Spec Issue 1:185-191

Nuttall PA (1984) Tick-borne viruses in seabird colonies. Seabird 7:31-41

Ogden NH, Maarouf A, Barker LK, Bigras-Poulin L, Lindsay LR, Morsehd MG, O'Callaghan CJ, Ramay F, Waltner-Toews D, Charron DF (2006) Climate change and the potential for range expansion of the Lyme disease vector Ixodes scapularis in Canada. Int J Parasitol 36:63-70

Olsen B, Duffy DC, Jaenson TGT, Gylfe A, Bonnedahl J, Bergström S (1993) A lyme borreliosis cycle in seabirds and Ixodes uriae ticks. Nature 362:340-342

Olsen B, Duffy DC, Jaenson TGT, Gylfe A, Bonnedahl J, Bergström S (1995) Transhemispheric exchange of Lyme disease spirochetes by seabirds. J Clin Microbiol 33:3270-3274

Smith RP, Rand PW, Lacombe EH, Morris SR, Holmes DW, Caporale DA (1996) Role of bird migration in the long-distance dispersal of Ixodes dammini, the vector of Lyme disease. J Infect Dis 174:221-224

Steig EJ, Schneider DP, Rutherford RD, Mann ME, Comisso JC, Shindell DT (2009) Warming of the Antarctic ice-sheet surface since the 1957 International Geophysical Year. Nature 457:459-463

Wilson N (1970) Metastigmata: Ixodidae of South Georgia, Heard and Kerguelen. Pac Insect Monogr 23:78-88 